\title{
Clinically Relevant Doses of Fluoxetine and Reboxetine Induce Changes in the TrkB Content of Central Excitatory Synapses
}

\author{
Ursula Wyneken', Mauricio Sandoval', Soledad Sandoval', Franscisco Jorquera', Ignacio González', \\ Francisco Vargas', Romina Falcon', Milena Monari' and Fernando Orrego*,' \\ 'Neuroscience Laboratory, Faculty of Medicine, Universidad de los Andes, Casilla, Santiago, Chile
}

\begin{abstract}
We have studied the effect of low doses of two widely used antidepressants, fluoxetine (Flx) and reboxetine (Rbx), on excitatory synapses of rat brain cortex and hippocampus. After 15 days of Flx treatment $(0.67 \mathrm{mg} / \mathrm{kg} / \mathrm{day})$, its plasma level was $20.7 \pm 5.6 \mathrm{ng} / \mathrm{ml}$. Analysis of postsynaptic densities (PSDs) by immunoblotting revealed no changes in the glutamate receptor subunits GluRI, NRI, NR2A/ $\mathrm{B}, \mathrm{mGluRI} \alpha$ nor in the neurotrophin receptor $\mathrm{p} 75^{\mathrm{NTR}}$. However, the brain-derived neurotrophic factor (BDNF) receptor TrkB decreased by $42.8 \pm 6 \%$, and remained decreased after 6 weeks of treatment. The BDNF and TrkB content in homogenates of cortex and hippocampus began to rise at 9 and 15 days, respectively, and remained high for up to 6 weeks. Similar results were obtained following chronic Rbx administration at $0.128 \mathrm{mg} / \mathrm{kg} /$ day. We propose that BDNF, whose synthesis is increased by antidepressants, and which is in part released at synaptic sites, binds to TrkB in PSDs, leading to the internalization of the BDNF-TrkB complex and, thus, to a decrease of TrkB in the PSDs. This was paralleled by greater levels of phosphorylated (ie activated) TrkB in the light membrane fraction, that contains signaling endosomes. The retrograde transport of endocyted BDNF/TrkB complexes from spines to cell bodies, where it activates the synthesis of more BDNF, is a protracted process, potentially requiring several cycles of TrkB/BDNF complex endocytosis and transport. This positive feedback mechanism may help explain the time-lag between drug administration and its therapeutic effect, that is, the antidepressant drug paradox.

Neuropsychopharmacology (2006) 31, 24I5-2423. doi: I 0. I 038/sj.npp. I 30 I052; published online 22 March 2006
\end{abstract}

Keywords: fluoxetine; reboxetine; postsynaptic density; glutamate receptors; BDNF; TrkB

\section{INTRODUCTION}

It has been estimated that, at least, 600 million persons now living shall suffer from depression during their lives (Nemeroff and Owens, 2002; Weissman et al, 1996). One of the most widely used drugs for the treatment of depression is fluoxetine (Flx), a selective serotonin reuptake inhibitor. More recently, reboxetine (Rbx), a selective norepinephrine reuptake inhibitor, has been introduced (Wong et al, 2000). In spite of extensive research it remains unclear why, if the effects of these drugs, that increase the action of monoamines, have maximal effects on this process in a matter of a few hours, their clinical effects have a time lag of 3-6 weeks (Nemeroff and Owens, 2002). This is the antidepressant drug paradox, which suggests that complex mechanisms, yet incompletely understood, develop only following chronic drug administration.

\footnotetext{
*Correspondence: Dr F Orrego, Neuroscience Laboratory, Faculty of Medicine, Universidad de los Andes, Casilla 20 106, Santiago 6782468, Chile, Tel: +562 412 9307, Fax: + 562214 1752,

E-mail: forrego@uandes.cl

Received 17 June 2005; revised II January 2006; accepted I 8 January 2006

Online publication: 27 January 2006 at http://www.acnp.org/citations/ Npp0 $12706050392 /$ default.pdf
}

Several lines of evidence suggest that the antidepressant drug action is mediated by the neurotrophin brain-derived neurotrophic factor (BDNF) (Castrén, 2004; Duman et al, 2000), which influences neurogenesis and synaptic function and plasticity in the adult nervous system (Lee et al, 2002; Ernfors and Bramham, 2003). However, most of these studies have been performed using high drug doses compared to those shown to be clinically effective for humans (eg $10-20 \mathrm{mg} / \mathrm{kg}$ in rats $v s 0.3-0.9 \mathrm{mg} / \mathrm{kg}$ in humans for Flx; and $20-40 \mathrm{mg} / \mathrm{kg}$ in rats $v s 0.15 \mathrm{mg} / \mathrm{kg}$ in humans for Rbx (eg Russo-Neustadt et al, 2004; Saarelainen et al, 2003; Coppell et al, 2003). Choosing comparatively high Flx doses in rats might have been related to the shorter half-life of Flx in rats relative to humans (Alvarez et al, 1998), as well as the finding that only such high doses are effective for animal models of depression, the interpretation of which is somewhat uncertain (Cryan et al, 2002).

The large differences in doses suggest the convenience of experimental studies done with lower doses, comparable to those used in patients, especially to interpret changes induced in the BDNF/TrkB system, which is proposed to mediate antidepressant effects.

BDNF acts on virtually all central neurons, but is synthesized primarily in pyramidal neurons of brain cortex and hippocampus and in dentate granule cells (Hofer et al, 
1990; Rocamora et al, 1996), all of which are excitatory. Therefore, we decided to study whether chronic administration of low doses of the antidepressants Flx and Rbx could affect excitatory synapses of brain cortex and hippocampus. Indeed, previous studies have proposed that effective anti-depressant treatments influence glutamatergic neurotransmission (Zarate et al, 2003). Specifically, we studied the biochemical composition of isolated postsynaptic densities (PSDs), a structure characteristic of excitatory synapses, and where signal transduction occurs. PSDs are known to contain glutamate and neurotrophin receptors, regulatory enzymes, cytoskeletal, and scaffolding proteins and other elements involved in the generation and regulation of the synaptic response (Ziff, 1997; Kennedy, 2000; Li et al, 2004). Following 15 days of drug administration, we isolated PSDs from brain cortex and hippocampus and analyzed their glutamate receptor and BDNF receptor (TrkB) content. It was found that $\operatorname{TrkB}$ levels were selectively reduced with a delayed time course. We propose a model by which these observations might provide a solution to the antidepressant drug paradox.

\section{METHODS}

\section{Drug Administration}

Flx $(0.65-0.75 \mathrm{mg} / \mathrm{kg}),\left(\operatorname{Prozac}^{\circledR}\right.$ solution, Eli Lilly, Indianapolis, Indiana, USA, $20 \mathrm{mg} / 5 \mathrm{ml}$ ) was administered daily, by mouth through a plastic tube, to male Sprague-Dawley rats $(220-280 \mathrm{~g})$. This dose is equivalent, on a per weight basis, to a $40 \mathrm{mg}$ Flx daily dose to a $60 \mathrm{~kg}$ person. Control rats received water.

Rbx (Prolift, Pharmacia, Italia SpA, Ascoli, Piceno, Italy) was injected intramuscularly, at a dose of $126 \mu \mathrm{g} / \mathrm{kg}$. Ground $4 \mathrm{mg}$ tablets were dissolved in 1:6 ethanol-olive oil. This dose is equivalent to $9 \mathrm{mg}$ for a $70-\mathrm{kg}$ human adult. Control rats were injected with corresponding volumes of 1:6 ethanol-olive oil.

Drug administration was carried out daily at 1200 . Rats were decapitated and trunk blood for measurements of Flx levels was collected $6 \mathrm{~h}$ after the last drug administration.

\section{Analysis of Serum Fluoxetine}

Blood was collected in heparinized tubes and serum separated by centrifugation at $3000 \mathrm{~g}$ for $5 \mathrm{~min}$ and stored at $-20^{\circ} \mathrm{C}$. For extraction, $0.5 \mathrm{ml}$ of serum was mixed with $0.5 \mathrm{ml}$ of phosphate-buffered saline (PBS) and $100 \mu \mathrm{l}$ of $500 \mathrm{ng} / \mathrm{ml}$ imipramine as internal standard. Samples were applied to solid phase extraction columns (spe VARIAN, Bond Elut Certify) following the instructions of the provider. The eluate was dried and redissolved in $50 \mu \mathrm{l}$ of mobile phase consisting of acetonitrile:PBS:triethylamine (6:4:0.08).

Of the reconstituted solution $10 \mu \mathrm{l}$ was injected into the LC system (Agilent HP series 1100 with UV detector). Chromatographic separation of Flx was accomplished on a HS-3 $\mathrm{C}_{18}$ column (Perkin Elmer, Boston, MA, USA) coupled with a $\mathrm{C}_{18}$ precolumn. The flow rate was maintained isocratically at $2 \mathrm{ml} / \mathrm{min}$. The eluate from the HPLC column was monitored at $220 \mathrm{~nm}$ and retention times were of 1.6 and $2.4 \mathrm{~min}$ for Flx and imipramine, respectively.
Linearity, precision, and sensitivity: Calibration curves from 25 to $200 \mathrm{ng} / \mathrm{ml} \mathrm{Flx} \mathrm{were} \mathrm{linear} \mathrm{and} \mathrm{were} \mathrm{constructed}$ with blank serum and standard solution. Peak-height ratios of Flx to the internal standard was measured at each nominal concentration $(25-200 \mathrm{ng} / \mathrm{ml})$ and used to construct nonweighted least-square linear regression curves with coefficients of determination ( $r^{2}$ values) $\geqslant 0.96$. The coefficient of variation $(\mathrm{CV})$ of the concentrations measured at different days (inter-run precision) never exceeded 15\%. The sensitivity was of $10 \mathrm{ng} / \mathrm{ml}$.

\section{Subcellular Fractionation}

Rats were killed by decapitation at varying intervals following the beginning of drug administration. Brains were quickly removed and placed in ice-cold homogenization buffer ((320 mM sucrose, $5 \mathrm{mM} \mathrm{N}$-(2-hydroxyethyl) piperazine- $N^{\prime}$-2-ethanesulfonic acid (HEPES), pH 7.4, containing protease inhibitor mixture (Complete, Boehringer Mannheim, Mannheim, Germany)). Cortices and hippocampi of five animals of the same experimental group were pooled and immediately homogenized. Synaptosomes, synaptic membranes, light membranes, and PSDs were collected as described previously (Soto et al, 2004). Briefly, following centrifugation at 1000 and $12000 \mathrm{~g}$, the P2 pellet (crude synaptosome fraction) was further fractionated by centrifuging at $200000 \mathrm{~g}$ for $60 \mathrm{~min}$ in a discontinuous $(0.85 / 1 / 1.2 \mathrm{M})$ sucrose gradient. The following fractions were collected: light membranes (LM1) at the $0.85 / 1 \mathrm{M}$ interphase and synaptosomes at the $1 / 1.2 \mathrm{M}$ sucrose interphase. The synaptosomal fraction was lysed for $30 \mathrm{~min}$ in 5 volumes of an ice-cold hypo-osmotic solution $(0.5 \mathrm{mM}$ EGTA, $5 \mathrm{mM}$ Tris-Cl, pH 8.1) and centrifuged at $33000 \mathrm{~g}$ for $30 \mathrm{~min}$. The resulting pellet was resuspended and centrifuged again in a $(0.85 / 1 / 1.2 \mathrm{M})$ sucrose step gradient. Synaptic membranes (at the $1 / 1.2 \mathrm{M}$ sucrose interphase) and a second light membrane fraction (LM2) (at the 0.85/ $1 \mathrm{M}$ interphase) were collected. Synaptic membranes were delipidated in $0.32 \mathrm{M}$ sucrose, $0.5 \%$ TritonX-100, $0.05 \mathrm{mM}$ $\mathrm{CaCl}_{2}, 1 \mathrm{mM}$ DTT, $5 \mathrm{mM}$ Tris $\mathrm{pH} 8.1$ to obtain PSDs. These were washed in $120 \mathrm{mM} \mathrm{KCl}, 50 \mathrm{mM}$ Hepes, $\mathrm{pH} 7.4$ and pelleted by a $10 \mathrm{~min}$ centrifugation at $100000 \mathrm{~g}$. All steps were performed at $0-4{ }^{\circ} \mathrm{C}$. Protein content was determined by the bicinchoninic acid method (Smith et al, 1985).

BDNF concentration in synaptosomes was measured by enzyme-linked immunosorbent assay (ELISA; BDNF Emax Immunassay System; Promega, Madison, WI, USA), using known concentrations of purified BDNF as standard.

\section{Western Blotting}

Protein $(20 \mu \mathrm{g})$ from subcellular fractions were dissolved at $1 \mathrm{mg} / \mathrm{ml}$ in gel loading buffer and separated by sodium dodecylsulfate polyacrylamide electrophoresis (SDS-PAGE) on 5-20\% gels under fully reducing conditions and transferred onto nitrocellulose membranes. Membranes were incubated overnight with antibodies against NR1 (Pharmingen, BD Biosciences, USA), NR2A/B (Chemicon), metabotropic glutamate-receptor subunit $1 \alpha$ (Pharmingen), $\alpha$-amino-3-hydroxy-5-methyl-4 isoxazole propionic acid (AMPA) receptor subunit GluR1 (Pharmingen), BDNF, Rab-5 and p75 ${ }^{\text {NTR }}$ (Santa Cruz Biotechnology, Santa Cruz, 
CA, USA) and TrkB (Transduction Laboratories and Santa Cruz Biotechnology) followed by incubation with horseradish peroxidase-conjugated secondary antibodies. Immunoreactivity was visualized using the ECL detection system (Amersham Buchler, Braunschweig, Germany).

\section{Immunoprecipitation of Phosphotyrosine}

For immunoprecipitation, both light membrane fractions were pooled. $200 \mu \mathrm{g}$ of protein was solubilized at $4{ }^{\circ} \mathrm{C}$ during $2 \mathrm{~h}$ in solubilization buffer consisting of $50 \mathrm{mM}$ Tris- $\mathrm{HCl}$ $\mathrm{pH} 7.5,150 \mathrm{mM} \mathrm{NaCl}, 10 \mathrm{mM}$ EDTA, $2 \mathrm{mM}$ EGTA, $0.1 \%$ SDS, $1 \%$ Triton-X100, 1\%CHAPS, 0.5\% NP-40, 0.1\% BSA, $50 \mathrm{mM} \mathrm{NaF}$ and $50 \mathrm{mM} \mathrm{Na}_{3} \mathrm{VO}_{4}$ plus protease inhibitors. Agarose covalently $(40 \mu \mathrm{l})$ coupled to the monoclonal antiphosphotyrosine antibody $4 \mathrm{G} 10$ (Upstate) was used for overnight immunoprecipitation. The immunoprecipitates were washed three times with solubilization buffer and resuspended in $50 \mu \mathrm{l}$ of electrophoresis loading buffer.

Rats were treated following the recommendations of the Chilean National Research Agency, Fondecyt, and the experimental protocols were approved by the Ethics Committee of Universidad de los Andes. Statistical analysis of densitometric quantification of the Western Blots was performed (one sample Student's t-test) using InStat3 obtained from GraphPad (San Diego, CA, USA).

Materials. All materials were from Sigma, except when specified.

\section{RESULTS}

\section{Measurement of Flx Plasma Levels}

Following 15 days of Flx administration, the serum level of Flx, measured $6 \mathrm{~h}$ after the last administration, was of
$20.7 \pm 5.6 \mathrm{ng} / \mathrm{ml}$. As a comparison, Flx serum levels in two additional groups of five rats each, was measured. One received a low i.p. Flx dose $(0.7 \mathrm{mg} / \mathrm{kg})$, and the other a high i.p. Flx dose $(10 \mathrm{mg} / \mathrm{kg})$ for 15 days. The Flx levels in these groups were $27 \pm 9.1$ and $81 \pm 10.3 \mathrm{ng} / \mathrm{ml}$, respectively. Thus, the route of administration of low doses of Flx did not result in significant differences in serum levels, but a high dose $(10 \mathrm{mg} / \mathrm{kg})$ resulted in increased Flx levels $(P<0.01)$. Further, the plasma Flx levels achieved with low doses were comparable to the effective therapeutic low-range drug levels found in human patients (Charlier et al, 2000).

\section{Effect of Chronic Flx or Rbx on PSD Composition}

After daily oral administration of Flx for 15 days, no changes were found in the composition of the PSDs regarding the glutamate receptor subunits GluR1, NR1, $\mathrm{NR} 2 \mathrm{~A} / \mathrm{B}$, or mGluR1 $\alpha$, belonging to the AMPA, $N$-methyl-Daspartate (NMDA), or metabotrobic receptor types, respectively (Figure 1). However, when the neurotrophin-related receptors were studied, a large decrease in $\operatorname{TrkB}$, the BDNF receptor, was found. This seemed selective as no change was seen in the low-affinity neurotrophin receptor, $\mathrm{p} 75^{\mathrm{NTR}}$, now also thought to be a high-affinity proneurotrophin receptor (Chao, 2003).

When the time course of the effect of daily administered Flx on the TrkB content in PSDs was followed in the 3-42 day interval (Figure 2), no change was seen at 3,6, or 9 days. At 12 days, a 12\%, nonsignificant, decrease was found, while at 15 days (same data as in Figure 1) the decrease was $42.8 \pm 6 \% \quad(P<0.01)$. This decrease remained significant after 42 days $(P<0.01)$, but was lower than at 15 days $(P<0.01)$. Rbx also decreased the TrkB content of PSDs, but to a lesser degree than Flx $(28.8 \pm 0.5 \%)$ after 15 days.
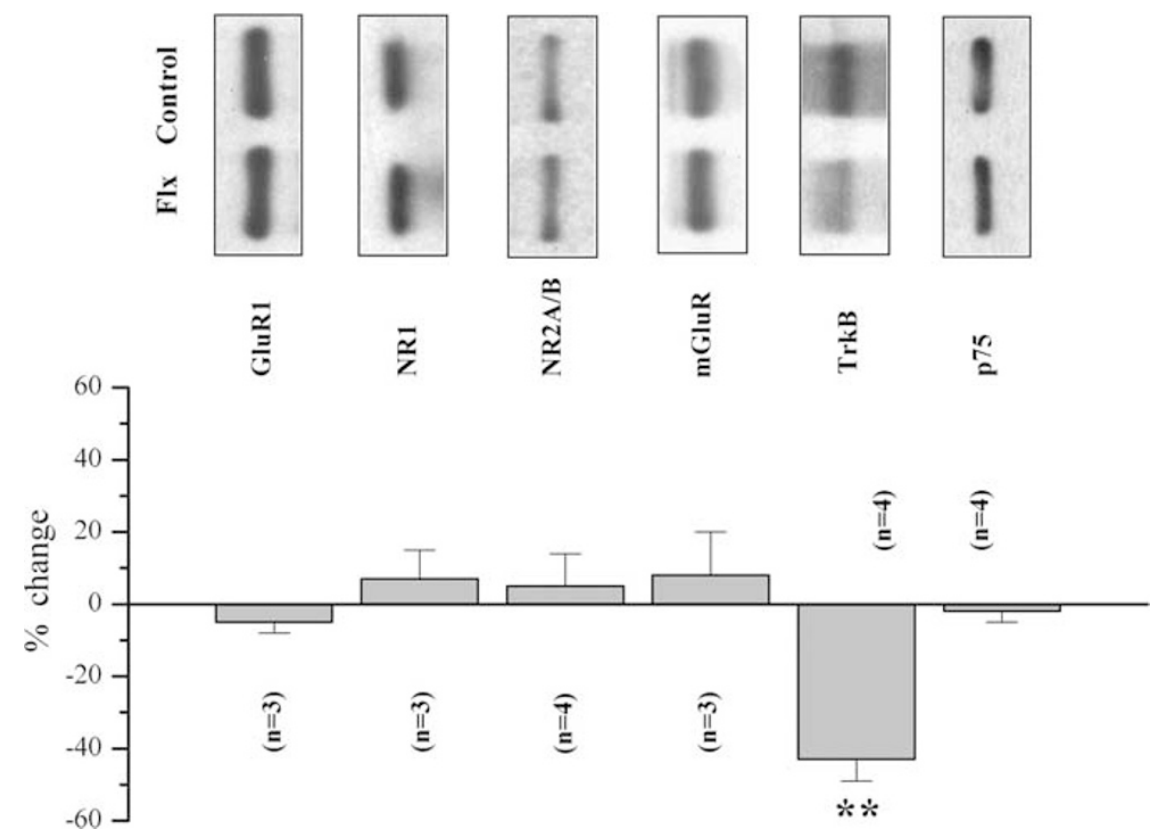

Figure I Glutamate and neurotrophin receptors in postsynaptic densities (PSDs) of fluoxetine-treated Rats. In the upper part, representative Western blots of PSDs obtained from control and Flx-treated rats are shown. Antibodies against the following receptor subunits were used: GluRI (AMPA receptor), $\mathrm{NRI}$ and NR2 A/B (NMDA receptor) and mGluR Iá (metabotropic receptors), as well as the BDNF receptor TrkB, and the low-affinity neurotrophin receptor $\mathrm{p} 75^{\mathrm{NTR}}$. In the lower part of the figure, the percent change due to Flx treatment of each of the indicated receptors, is shown. $\mathrm{n}$ is the number of independent experiments, each representing the value obtained from PSDs pooled from four rat brains (* $P<0.05$; $* * * 0.0$ I). 


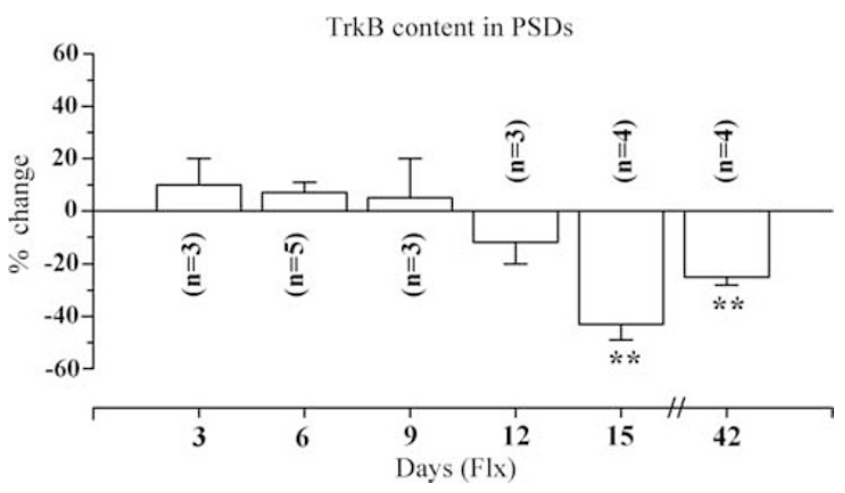

Figure 2 Time course of Flx-induced changes in the TrkB content in PSDs. Mean \pm SEM TrkB changes at different time points are shown. $(* * P<0.0 I)$. The differences between bars at I 5 and 42 days are significant $(P<0.05)$. Data at 15 days are the same as in Figure I.

\section{TrkB content in PSDs}
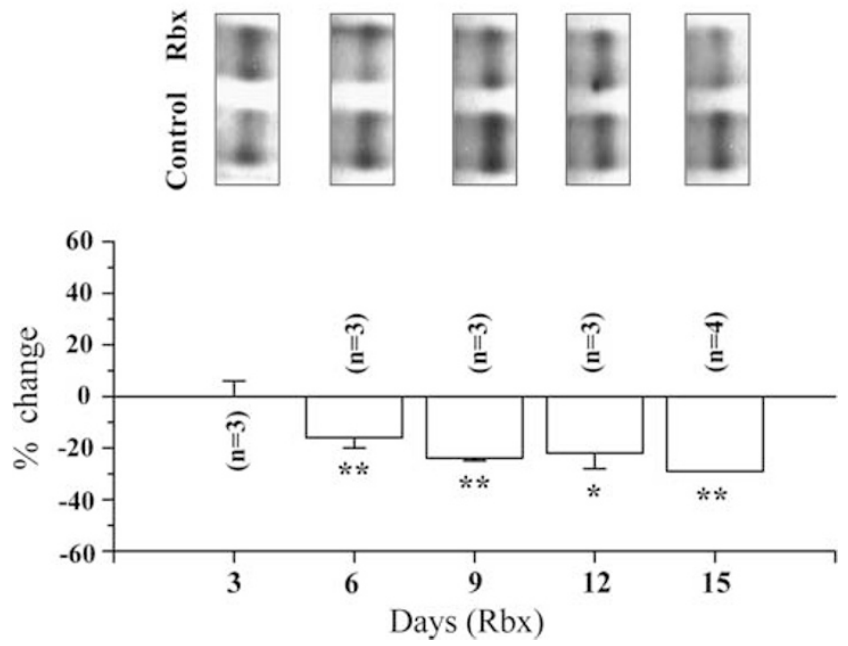

Figure 3 Time course of Reboxetine-induced changes in the TrkB content in PSDs. Representative Western blots are shown in the upper part, and mean \pm SEM\% change of TrkB content in the lower part $(* P<0.05$; $* * P<0.01)$.

Such a decrease in response to Rbx became apparent at 6 days and TrkB levels remained low at least for 15 days (Figure 3). Similarly to Flx-treated rats, the glutamate receptor subunits in PSDs did not change with $\mathrm{Rbx}$ (not shown).

\section{Effect of Flx on TrkB and BDNF Levels in Whole Tissue}

To test whether the decrease in TrkB might be due to a general decrease in receptor levels, the effect of Flx on TrkB content was studied over a 3-42 day interval in homogenates of brain cortex and hippocampus (Figure 4). No changes were seen at 3 or 6 days, while a nonsignificant increase was observed at 9 days. This effect became significant at 12 days $(P<0.05)$, and continued to be so at 15 and 42 days.

During the same time interval, Flx treatment led to a large increase in BDNF tissue levels (Figure 5; note the different ordinate scale compared to Figure 4). This increase started at 9 days and persisted up to 42 days, with the values from

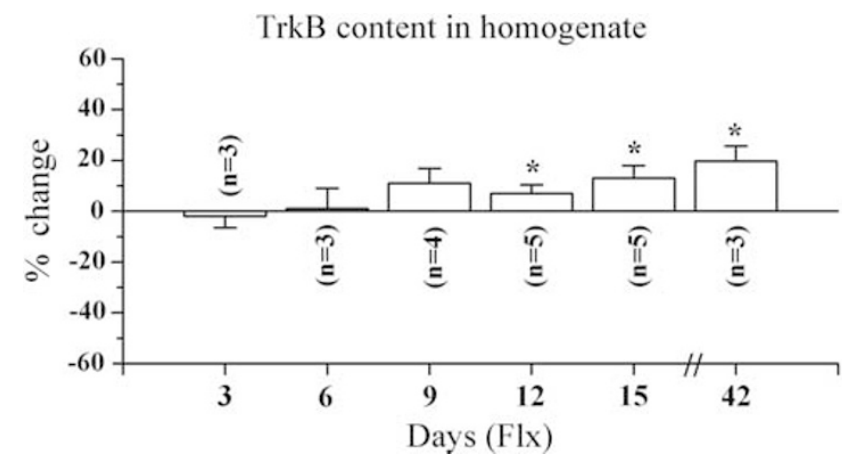

Figure 4 Time course of Flx-induced changes in the TrkB content in homogenates of cortex and hippocampus. Mean \pm SEM TrkB changes are shown $(* P<0.05)$

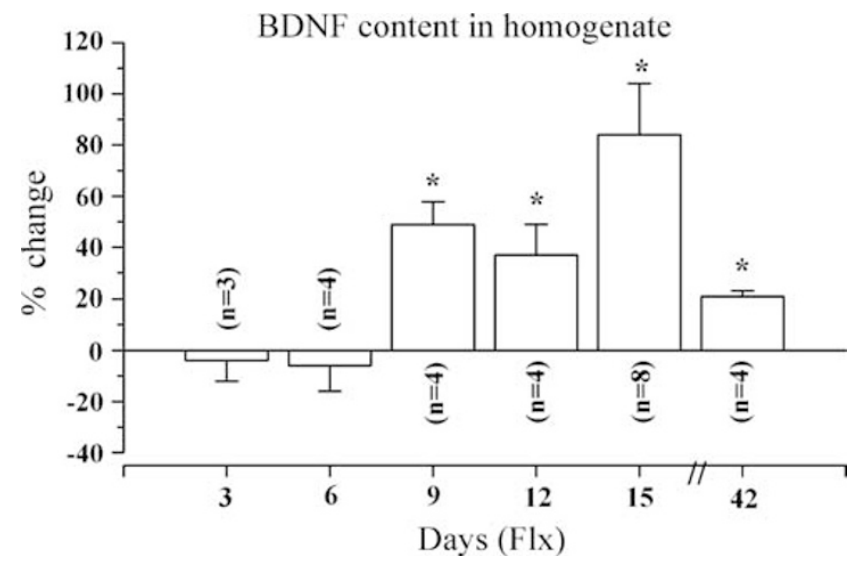

Figure 5 Time course of Flx-induced changes in the BDNF content in homogenates of cortex and hippocampus. Mean \pm SEM BDNF changes are shown $(* P<0.05)$

9 days onwards being significant $(P<0.05)$. Rbx also increased significantly the BDNF content of homogenates, but to a lesser extent than Flx (Figure 6). In the same time range, $\mathrm{Rbx}$ also increased TrkB levels in the homogenates by $10-30 \%$ (not shown). This effect, although small, was significant at 15 days $(P<0.05)$, and also indicated that the Rbx-induced decrease of TrkB in PSDs was not due to a general decrease in receptor levels, but was specific to the PSD.

\section{TrkB is Increased and Activated in Subcellular Fractions that are Enriched in Intracellular Membranes}

As TrkB levels in PSDs were decreased after 15 days of treatment, we hypothesized that BDNF, which is elevated after treatment, presumably leading to enhanced BDNF release at synaptic sites, might interact with TrkB at the PSD causing increased internalization of the TrkB/BDNF complex and thus a decrease of TrkB in the PSDs. We therefore measured the BDNF and TrkB content in synaptosomes, that contain various intrasynaptosomal membranes, and in the synaptic membrane fraction, which is devoid of intracellular components, but contain PSDs. In the synaptic membrane fraction, intracellular components were eliminated by lysis of synaptosomes followed by density gradient 


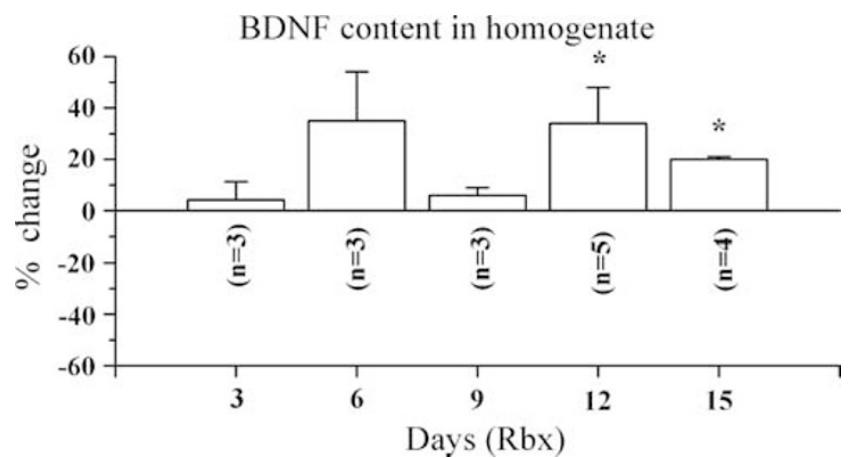

Figure 6 Time course of Rbx-induced changes in the BDNF content in homogenates of cortex and hippocampus. Mean \pm SEM BDNF changes are shown $(* P<0.05$; $* * P<0.01)$.

centrifugation. Consistent with our hypothesis, the TrkB and BDNF content was increased in synaptosomes, whereas TrkB was decreased in synaptic membranes, that also contain the PSDs (Figure 7a). The BDNF content in synaptosomes, measured by Elisa, increased by $25 \%$ (from $525 \pm 2$ to $655 \pm 14$ (mean \pm SEM) ng/g of synaptosomal protein), while the BDNF content in synaptic membranes was under the limit of detection under the same assay conditions. In conclusion, as a result of Flx treatment, the TrkB and BDNF content in whole homogenates increased, while TrkB decreased in PSDs as well as in synaptic membranes. In the endosome-containing light membrane fraction derived from Flx-treated rats, however, an increase in tyrosine-phosphorylated (ie activated) TrkB was found (Figure $7 \mathrm{~b}$ ). We also studied the localization of Rab-5, a selective marker for early endosomes, in light membranes obtained from the first (LM1) and second (LM2) sucrose gradients, as well as in synaptosomes, synaptic membranes and PSDs (Figure 7c). Rab-5 was enriched in both light membrane fractions, the same ones in which phosphorylated TrkB is present, while it was absent from PSDs. The above observations are consistent with the notion that TrkB is activated by BDNF and endocytosed, in accordance with the hypothesis of a Flx-induced increase in BDNF release from axon terminals.

\section{DISCUSSION}

\section{Low Levels of Flx and Rbx Induce Specific Changes in} Forebrain Synapses

These results show for the first time that low doses of antidepressants induce specific changes in rat forebrain excitatory synapses. The high doses used in other previous studies $(5-20 \mathrm{mg} / \mathrm{kg})$ were chosen because of the shorter half-life of these drugs in rats relative to humans, regardless of the very high plasma levels achieved at $4-6 \mathrm{~h}$ after administration (Perrone et al, 2004; Alvarez et al, 1998). Such peak levels are much higher than those commonly observed in patients, and may produce adverse reactions (Isbister et al, 2004). In rats, a chronic Flx dose of $10 \mathrm{mg} / \mathrm{kg}$ causes anorexia, which may be related to an overall toxicity, as the lethal dose in rats is only two to three times greater (Caccia et al, 1992). The nonlinear relationship between Flx plasma and brain levels may help to explain such toxicity
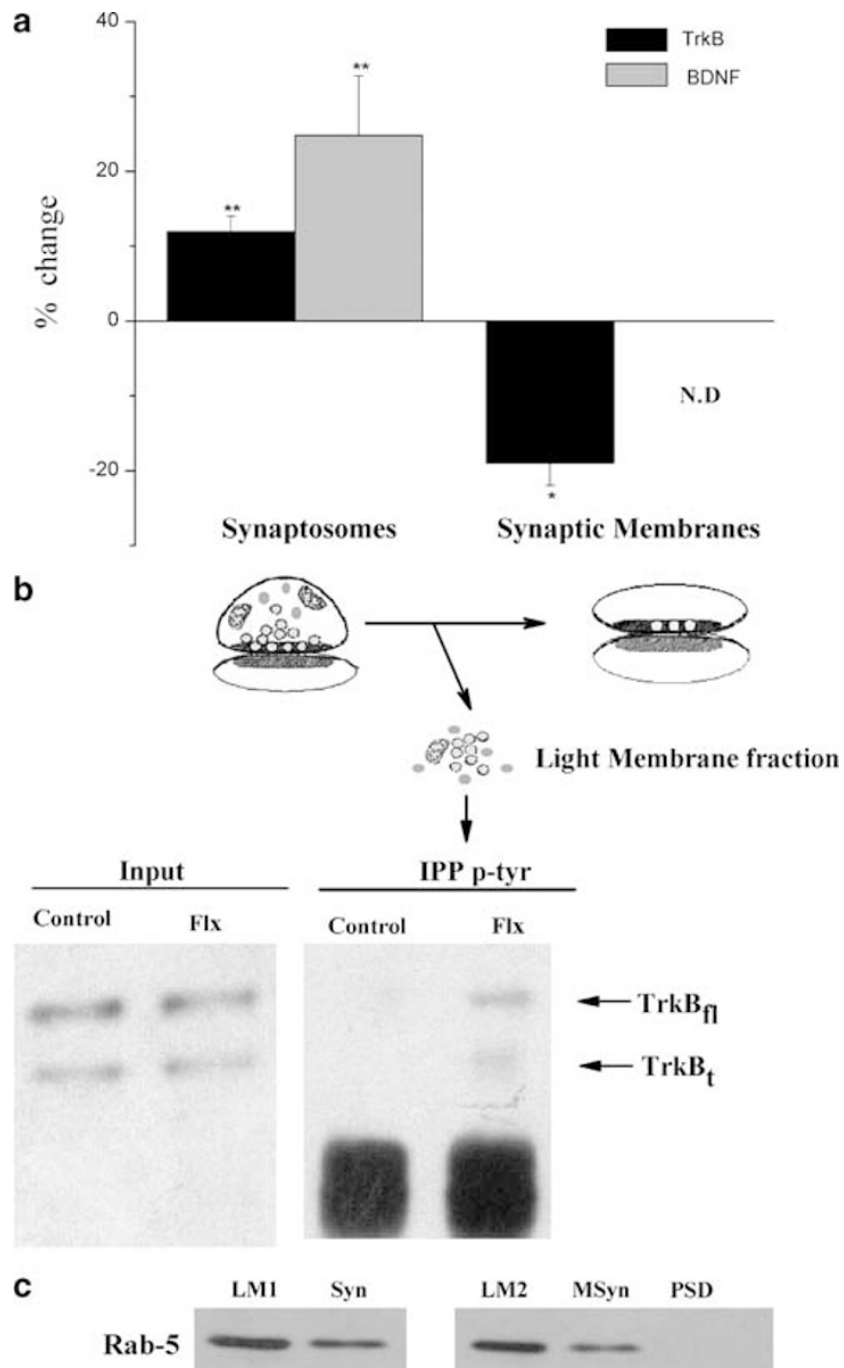

Figure 7 (a) Changes in the TrkB and BDNF content in synaptosomes and synaptic membranes after I 5 days of Flx treatment $(n=5$ independent subcellular fractionation procedures, ${ }^{*} P<0.05$; ${ }^{*} * P<0.0 I$ ). (b) Phosphorylated TrkB is increased in light membranes after 15 days of Flx treatment. Left panel: input, Western blot of TrkB in the starting material. Right panel: Immunoprecipitation of phospho-tyrosine, followed by Western Blot of TrkB. The antibody used recognizes the extracellular domain of TrkB. Therefore, both TrkB isoforms are seen ( $f=$ full length, about $145 \mathrm{kDa}$; $\mathrm{t}=$ truncated, about $90 \mathrm{kDa}$ ). (c) Rab-5, a marker for early endosomes, is enriched in both light membrane fractions. Western blot using an anti-Rab5 antibody of the following subcellular fractions is shown: light membranes obtained from the first sucrose gradient (LMI), synaptosomes (Syn), light membranes obtained from the second sucrose gradient (LM2), synaptic membranes (MSyn), and PSDs. Each lane was loaded with $20 \mu \mathrm{g}$ of protein

(Caccia et al, 1997). High doses of Flx have been also used in behavioral studies, although it seems uncertain whether Flx effects in animal models of anxiety or stress are related to its antidepressant activity (Cryan et al, 2002). Others have studied behavioral effects of acute administration of the drug, which again, may have no relationship with antidepressant activity (Hirano et al, 2005). However, one study by Contreras et al (2001) described physiological and behavioral changes in rats after a chronic (21 days), but not acute, dose of $0.5-1 \mathrm{mg} / \mathrm{kg}$, which is equivalent to the one used by us. 
In the cat using PET with Carbon 11-labeled 3-amino-4(2-dimethylaminomethyl-phenylsulfanyl)-benzonitrile $\left({ }^{11} \mathrm{C}\right.$ DASB), a selective ligand for serotonin transporters (SERTs), it was shown that a single Flx dose of $1 \mathrm{mg} / \mathrm{kg}$ i.v., resulted in $90 \%$ occupancy of SERTs of striatum, thalamus and midbrain, and a $78 \%$ occupancy in cortex. This effect lasted for 2 days, with a $t_{1 / 2}$ of occupancy of 9 days (Ginovart et al, 2003).

In depressed patients, Bolo et al, 2000, using Magnetic Resonance Spectroscopy of the ${ }^{19} \mathrm{~F}$ signal naturally present in Flx and norfluoxetine (NFlx), found that doses of Flx of $10-40 \mathrm{mg} /$ day for 3-12 months resulted in Flx brain concentrations of $13 \pm 7 \mu \mathrm{M}$, that, using 0.0023 as the unbound fraction (Liu et al, 2005), would give a drug concentration of $39 \mathrm{nM}$, that is 13 times the $K_{i}$ for Flx in human SERTs (Demchyshyn et al, 1994). Similar results were obtained by Strauss et al (2002). However, the effective Flx serum concentration in patients is uncertain, because serum levels are highly variable among responders, ranging from 28 to $300 \mathrm{ng} / \mathrm{ml}$. In addition, no relationship between therapeutic effect and plasma concentration has been shown (Amsterdam et al, 1997; Charlier et al, 2000; Wilens et al, 2002). It is also of interest that in depressed patients there is a significant increase in the plasma protein alpha 1-acid glycoprotein (AAG) (Nemeroff et al, 1990), one of the major binding sites for Flx in plasma (the other one is serum albumin). Such an increase in AAG leads to a rise in total Flx concentration in plasma, but decreases the unbound fraction leading to a decrease in Flx and NFlx concentrations in the brain (Holladay et al, 1998).

\section{Decrease of TrkB in PSDs}

The composition and purity of the PSDs isolated by us has been described previously (Smalla et al, 2000; Wyneken et al, 2001; Li et al, 2004). The delayed decrease of TrkB in PSDs and synaptic membranes observed here may result as a consequence of increased BDNF release following antidepressant treatment. Flx acutely inhibits neuronal reuptake of serotonin, and this monoamine is able to potentiate the action of excitatory stimuli on cortical pyramidal neurons, for example, through inhibition of Ca-activated $\mathrm{K}$ channels (Aghajanian, 1995; Ansanay et al, 1995; Araneda and Andrade, 1991; Foehring et al, 2002; Goaillard and Vincent, 2002; Torres et al, 1995; Wallén et al, 1989) or inhibition of voltage-activated K channels (Aghajanian, 1995; Andrade and Nicoll, 1987; Beck, 1992). Similar proexcitatory effects have been also described for norepinephrine (Larkman and Kelly, 1992; Lee and McCormick, 1996; Madison and Nicoll, 1986a, b; McCormick et al, 1991). Increased serotonin or norepinephrine in the synaptic cleft could thus induce a moderate neuronal excitation and, as a consequence, an increase in BDNF synthesis and release. In the regions studied by us, BDNF is synthesized in pyramidal neurons of brain cortex and hippocampus and in the granule neurons of the dentate gyrus, all of which are excitatory, while TrkB is synthesized both in pyramidal and nonpyramidal cells (Cellerino et al, 1996; Hofer et al, 1990; Rocamora et al, 1996). This increased BDNF in the synaptic cleft would bind to and activate $\operatorname{TrkB}$, a proportion of which is in PSDs. Binding of neurotrophins to their receptors induces the endocytosis of the neurotrophin-receptor complex (Grimes and Miettinen, 2003; Howe et al, 2001; Huang and Reichardt, 2003; Watson et al, 1999; York et al, 2000). The TrkB/BDNF complex should then, at least in part, be retrogradely transported from the spines to the cell body, where it enhances further BDNF synthesis. This process is part of a self-sustained loop with positive feed-back as has been proposed by Castrén (2004). BDNF increases the synthesis of additional BDNF which, when secreted and endocytosed by other connected pyramidal neurons, further increases the synthesis of BDNF in these recipient neurons.

It is known that neuronal activation, or increases in cAMP and intracellular $\mathrm{Ca}^{2+}$, lead to the translocation of TrkB from the cytoplasm to the plasma membrane (MeyerFranke et al, 1998; Ji et al, 2005), and that excitation in experimental and human epilepsy greatly increases the TrkB content in PSDs (Wyneken et al, 2001, 2003). As the increase of $\operatorname{TrkB}$ and BDNF is associated with neuronal activation, the decrease of TrkB in PSDs observed here is unlikely to be due to a decreased incorporation, but rather to an increased endocytosis of the BDNF/TrkB complex. If the rate of incorporation of the receptor to the PSD is less than its rate of transfer from the PSD to endocytic vesicles, then the overall concentration of TrkB at the PSD shall be reduced. The increase of BDNF and of activated TrkB in subcellular fractions that contain endocytic vesicles supports our hypothesis that the BDNF/TrkB complex follows the endocytic pathway.

The 3-6 week lag that exists between the time that antidepressant drugs inhibit monoamine reuptake, and the rapid subsequent extracellular increase of these amines (Fuller, 1994), and the slow clinical efficay of the drugs, may be explained by processes that take time (ie transport of BDNF along axons, enhanced secretion of it, endocytosis and backtransport of the BDNF/TrkB complex followed by enhanced synthesis of BDNF, that leads to further secretion), as those described in this study. The decrease of TrkB in PSDs lags behind the Flx or Rbx-induced increase in whole tissue content of BDNF, as TrkB shall decrease in them, due to endocytosis, only when BDNF reaches axon terminals and is secreted in relatively large amounts.

In the present work, we have concentrated on antidepressant-enhanced BDNF release from axon terminals, which is monitored through the decrease in PSD-TrkB. However, the trophic and synaptic effects of BDNF are probably the most relevant events related to antidepressant action. Saarelainen et al (2003) have shown that activation of TrkB is necessary for the antidepressant effect of high doses of imipramine and Flx, and that these drugs also increase the release of BDNF. Such findings are consistent with the hypothesis proposed here.

\section{Excitatory Synapses, BDNF and Antidepressant Effects}

The magnitude of the antidepressant-induced decrease of TrkB in PSDs (ie 42.8 and $28.8 \%$ for Flx and Rbx, respectively) also suggests that a very high proportion of excitatory synapses in brain cortex and hippocampus are affected by the treatment, thus supporting the suggestion of Nestler et al (2002) that depression affects many brain regions. The fact that the relative amount of glutamate receptors in PSDs does not change with treatment, is not necessarily inconsistent with an increase in the number of 
synaptic contacts, as we have only measured the concentration of glutamate and BDNF receptors at the PSD, not their absolute amounts, which could give some indication of the total number of synaptic contacts.

The findings reported here, in which the BDNF/TrkB system of central excitatory synapses is involved, are of interest, because antidepressant drugs, as well as electroconvulsive therapy, magnetic stimulation and even physical exercise are known cerebrocortical activators (RussoNeustadt et al, 1999). The activation of pyramidal neurons would thus be a common element in the action of many of the currently used antidepressant treatments.

The present results fulfill the criteria set forth by Coyle and Duman (2003) for validating the action of antidepressant drugs: (1) the effects should occur at clinically relevant drug doses, (2) the effects should be seen after chronic but not acute treatment and, (3) the mechanism of action should involve neuronal systems that have relevance to mood regulation. Many studies have shown the relationship between BDNF and both depression and antidepressant treatments (Castrén 2004; Chen et al, 2001; Duman et al, 1997; Duman and Vaidya, 1998; Nestler et al, 2002; Nibuya et al, 1996; Shirayama, 2002; Zetterstrom et al, 1998). In the present work, we have further consolidated this relationship by showing that antidepressant drugs cause large changes in the BDNF-TrkB system in excitatory synapses which are very abundant in mammalian brain cortex and hippocampus.

\section{ACKNOWLEDGEMENTS}

This work was Supported by Universidad de los Andes Project No. MED 005-03 and 005-05, Farmacias CruzVerde and Fondecyt 1020257.

\section{REFERENCES}

Aghajanian GK (1995). Electrophysiology of serotonin receptor subtypes and signal transduction pathways. In: Bloom FE, Kupfer DJ (eds). Psychopharmacology: The Fourth Generation of Progress. Raven Press: New York, pp 451-460 ( www.acnp.org/ g4/GN 401000043/Ch043.html ).

Alvarez JC, Bothua D, Collignon I, Advenier C, Spreux-Varoquaux O (1998). Determination of fluoxetine and its metabolite norfluoxetine in serum and brain areas using high-performance liquid chromatography with ultraviolet detection. J Chromatogr B Biomed Sci Appl 707: 175-180.

Amsterdam JD, Fawcett J, Quitkin FM, Reimherr FW, Rosenbaum JF, Michelson D et al (1997). Fluoxetine and norfluoxetine plasma concentrations in major depression: a multicenter study. Am J Psychiatry 154: 963-969.

Andrade R, Nicoll RA (1987). Pharmacologically distinct actions of serotonin on single pyramidal neurons of the rat hippocampus recorded in vitro. J Physiol Lond 394: 99-124.

Ansanay H, Dumuis A, Sebben M, Bockaert J, Fagni L (1995). cAMP-dependent, long-lasting inhibition of a $\mathrm{K}^{+}$current in mammalian neurons. Proc Natl Acad Sci USA 92: 6635-6639.

Araneda R, Andrade R (1991). 5-Hydroxytryptamine 2 and 5hydroxytryptamine $1 \mathrm{~A}$ receptors mediate opposing responses on membrane excitability in rat association cortex. Neuroscience 40: 399-412.

Beck SG (1992). 5-Hydroxytryptamine increases excitability of CA1 hippocampal cells. Synapse 10: 334-340.
Bolo NR, Hode Y, Nedelec JF, Laine E, Wagner G, Macher JP (2000). Brain pharmacokinetics and tissue distribution in vivo of fluvoxamine and fluoxetine by fluorine magnetic resonance spectroscopy. Neuropsychopharmacology 23: 428-438.

Caccia S, Bizzi A, Coltro G, Fracasso C, Frittoli E, Mennini T et al (1992). Anoretic activity of fluoxetine and norfluoxetine in rats: relationship between brain concentrations and in-vitro potencies on monoaminergic mechanisms. J Pharm Pharmacol 44: $250-254$.

Caccia S, Confalonieri S, Bergami A, Fracasso C, Anelli M, Garattini S (1997). Neuropharmacological effects of low and high doses of repeated oral dexfenfluramine in rats: a comparison with fluoxetine. Pharmacol Biochem Behav 57: 851-856.

Castrén E (2004). Neurotrophic effects of antidepressant drugs. Curr Opin Pharmacol 4: 58-64.

Cellerino A, Maffei L, Domenici L (1996). The distribution of brain-derived neurotrophic factor and its receptor trkB in parvalbumin - containing neurons of the rat visual cortex. Eur J Neurosci 8: 1190-1197.

Chao MV (2003). Neurotrophins and their receptors: a convergence point for many signalling pathways. Nature Rev Neurosci 4: 299-309.

Charlier C, Pinto E, Ansseau M, Plomteux G (2000). Relationship between clinical effects, serum drug concentration, and concurrent drug interactions in depressed patients treated with citalopram, fluoxetine, clomipramine, paroxetine or venlafaxine. Hum Psychopharmacol 15: 453-459.

Chen B, Dowlatshahi D, MacQueen GM, Wang JF, Young LT (2001). Increased hippocampal BDNF immunoreactivity in subjects treated with antidepressant medication. Biol Psychiatr 50: $260-265$.

Contreras CM, Rodriguez-Landa JF, Gutierrez-Garcia AG, BernalMorales B (2001). The lowest effective dose of fluoxetine in the forced swim test significantly affects the firing rate of lateral septal nucleus neurones in the rat. J Psychopharmacol 15: 231-236.

Coppell AL, Pei Q, Zetterström TSC (2003). Bi-phasic change in BDNF gene expression following antidepressant drug treatment. Neuropharmacology 44: 903-910.

Coyle JT, Duman RS (2003). Finding the intracellular signaling pathways affected by mood disorder treatments. Neuron 38: 157-160.

Cryan JF, Markou A, Lucki I (2002). Assessing antidepressant activity in rodents: recent developments and future needs. Trends Pharmacol Sci 23: 238-245.

Demchyshyn LL, Pristupa ZB, Sugamori KS, Barker EL, Blakely $\mathrm{RD}$, Wolfgang WJ et al (1994). Cloning, expression, and localization of a chloride-facilitated, cocaine-sensitive serotonin transporter from Drosophila melanogaster. Proc Natl Acad Sci USA 91: 5158-5162.

Duman R, Malberg J, Nakagawa S, D'Sa C (2000). Neuronal plasticity and survival in mood disorders. Biol Psychiaty 48: 732-739.

Duman RS, Heninger GR, Nestler EJ (1997). A molecular and cellular theory of depression. Arch Gen Psychiatr 54: 597-606.

Duman RS, Vaidya VA (1998). Molecular and cellular actions of chronic electroconvulsive seizures. J ECT 14: 181-193.

Ernfors P, Bramham CR (2003). The coupling of a trkB tyrosine residue to LTP. Trends in Neurosci 26: 171-173.

Foehring RC, van Brederode JF, Kinney GA, Spain WJ (2002). Serotonergic modulation of supragranular neurons in rat sensorimotor cortex. J Neurosci 22: 8238-8250.

Fuller RW (1994). Uptake inhibitors increase extracellular serotonin concentration measured by brain microdialysis. Life Sci 55: 163-167.

Ginovart N, Wilson AA, Meyer JH, Hussey D, Houle S (2003). [11C]-DASB, a tool for in vivo measurement of SSRI-induced 
occupancy of the serotonin transporter: PET characterization and evaluation in cats. Synapse 47: 123-133.

Goaillard J-M, Vincent P (2002). Serotonin suppresses the slow afterhyperpolarization in rat intralaminar and midline thalamic neurons by activating $5-\mathrm{HT}_{7}$ receptors. J Physiol Lond 541: 453-465.

Grimes ML, Miettinen HM (2003). Receptor tyrosine kinase and G-protein coupled receptor signaling and sorting within endosomes. J Neurochem 84: 905-918.

Hirano K, Kimura R, Sugimoto Y, Yamada J, Uchida S, Kato Y et al (2005). Relationship between brain serotonin transporter binding, plasma concentration and behavioral effect of selective serotonin reuptake inhibitors. Br J Pharmacol 144: 695-702.

Hofer M, Pagliusi SR, Hohn A, Leibrock J, Barde Y-A (1990). Regional distribution of brain-derived neurotrophic factor mRNA in the adult mouse brain. EMBO J 9: 2459-2464.

Holladay JW, Dewey MJ, Yoo SD (1998). Kinetic interaction between fluoxetine and imipramine as a function of elevated serum alpha-1-acid glycoprotein levels. J Pharm Pharmacol. 50: 419-424.

Howe CL, Valletta JS, Rusnak AS, Mobley WC (2001). NGF signaling from clathrin - coated vesicles: evidence that signaling endosomes serve as a platform for the Ras-MAPK pathway. Neuron 32: 801-814

Huang EJ, Reichardt LF (2003). Trk receptors: roles in neuronal signal transduction. Ann Rev Biochem 72: 609-642.

Isbister GK, Bowe SJ, Dawson A, Whyte IM (2004). Relative toxicity of selective serotonin reuptake inhibitors (SSRIs) in overdose. J Toxicol Clin Toxicol 486: 277-285.

Ji Y, Pang PT, Feng L, Lu B (2005). Cyclic AMP controls BDNFinduced TrkB phosphorylation and dendritic spine formation in mature hippocampal neurons. Nat Neurosci 8: 164-172.

Kennedy MB (2000). Signal-processing machines at the postsynaptic density. Science 290: 750-754.

Larkman PM, Kelly JS (1992). Ionic mechanisms mediating 5-hydroxytryptamine-and noradrenaline-evoked depolarization of adult rat facial motoneurones. J Physiol London 456: 473-490.

Lee J, Duan W, Mattson MP (2002). Evidence that brain-derived neurotrophic factor is required for basal neurogenesis and mediates, in part, the enhancement of neurogenesis by dietary restriction in the hippocampus of adult mice. J Neurochem 82: $1367-1375$

Li KW, Hornshaw MP, Van Der Schors RC, Watson R, Tate S, Casetta B et al (2004). Proteomics analysis of rat brain postsynaptic density. Implications of the diverse protein functional groups for the integration of synaptic physiology. J Biol Chem 279: 987-1002.

Lee KH, McCormick DA (1996). Abolition of spindle oscillations by serotonin and norepinephrine in the ferret lateral geniculate and perigeniculate nuclei in vitro. Neuron 17: 309-321.

Liu X, Smith BJ, Chen C, Callegari E, Becker SL, Chen X et al (2005). Use of a physiologically based pharmacokinetic model to study the time to reach brain equilibrium: an experimental analysis of the role of blood-brain barrier permeability, plasma protein binding, and brain tissue binding. J Pharmacol Exp Ther 13: $1254-1262$

Madison DV, Nicoll RA (1986a). Actions of noradrenaline recorded intracellularly in rat hippocampal CA1 pyramidal neurons, in vitro. I Physiol 372: 221-244.

Madison DV, Nicoll RA (1986b). Cyclic adenosine 3', 5'-monophosphate mediates beta-receptor actions of noradrenaline in rat hippocampal pyramidal cells. J Physiol London 372: 245-259.

McCormick DA, Pape HC, Williamson A (1991). Actions of norepinephrine in the cerebral cortex and thalamus: implications for function of the central noradrenergic system. Prog Brain Res 88: 293-305.

Meyer-Franke A, Wilkinson GA, Kruttgen A, Hu M, Munro E, Hanson MG et al (1998). Depolarization and cAMP elevation rapidly recruit TrkB to the plasma membrane of CNS Neurons. Neuron 21: 681-693.

Nemeroff CB, Krishnan KR, Blazer DG, Knight DL, Benjamin D, Meyerson LR (1990). Elevated plasma concentrations of alpha 1-acid glycoprotein, a putative endogenous inhibitor of the tritiated imipramine binding site, in depressed patients. Arch Gen Psychiatry 47: 337-340.

Nemeroff CB, Owens MJ (2002). Treatment of mood disorders. Nature Neurosci suppl 5: 1068-1070.

Nestler EJ, Barrot M, DiLeone RJ, Eish AJ, Gold SJ, Monteggia LM (2002). Neurobiology of depression. Neuron 34: 13-25.

Nibuya M, Nestler EJ, Duman RS (1996). Chronic antidepressant administration increases the expression of cAMP response element binding protein (CREB) in rat hippocampus. J Neurosci 16: 2365-2372.

Perrone JA, Chabla JM, Hallas BH, Horowitz JM, Torres G (2004). Weight loss dynamics during combined fluoxetine and olanzapine treatment. BMC Pharmacol 4: 27.

Rocamora N, Welker E, Pascual M, Soriano E (1996). Upregulation of BDNF mRNA expression in the barrel cortex of adult mice after sensory stimulation. J Neurosci 16: 4411-4419.

Russo-Neustadt A, Beard RC, Cotman CW (1999). Exercise, antidepressant medications, and enhanced brain derived neurotrophic factor expression. Neuropsychopharmacol 21: 679-682.

Russo-Neustadt AA, Alejandre H, Garcia C, Ivy AS, Chen MJ (2004). Hippocampal Brain-Derived Neurotrophic Factor Expression Following Treatment with Reboxetine, Citalopram, and Physical Exercise. Neuropsychopharmacology 29: 21892199.

Saarelainen T, Hendolin P, Lucas G, Koponen E, Sairanen M, MacDonald E et al (2003). Activation of the TrkB neurotrophin receptors is induced by antidepressant drugs and is required for antidrepressant-induced behavioral effects. $J$ Neurosci 23: 349-357.

Shirayama Y (2002). Brain-derived neurotrophic factor produces antidepressant effects in behavioral models of depression. J Neurosci 22: 3251-3261.

Smalla KH, Matthies H, Langnase K, Shabir S, Bockers TM, Wyneken U et al (2000). The synaptic glycoprotein neuroplastin is involved in long-term potentiation at hippocampal CA1 synapses. Proc Natl Acad Sci USA 97: 4327-4332.

Smith PK, Krohn RI, Hermanson GT, Mallia AK, Gartner FH, Provenzano MD et al (1985). Measurement of protein using bicinchoninic acid. Anal Biochem 150: 76-85. Erratum in: Anal Biochem 1987;163:279.

Soto D, Pancetti F, Marengo JJ, Sandoval M, Sandoval R, Orrego F et al (2004). Protein kinase CK2 in postsynaptic densities: phosphorylation of PSD-95/SAP90 and NMDA receptor regulation. Biochem Biophys Res Commun 322: 542-550.

Strauss WL, Unis AS, Cowan C, Dawson G, Dager SR (2002). Fluorine magnetic resonance spectroscopy measurement of brain fluvoxamine and fluoxetine in pediatric patients treated for pervasive developmental disorders. Am J Psychiatry 159: 755-760.

Torres GE, Chaput Y, Andrade R (1995). Cyclic AMP and protein kinase A mediate 5-hydroxytryptamine type 4 receptor regulation of calcium-activated potassium current in adult hippocampal neurons. Mol Pharmacol 47: 191-197.

Wallén P, Buchanan JT, Grillner S, Hill RH, Christenson J, Hökfelt T (1989). Effects of 5-Hydroxytryptamine on the after hyper polarization, spike frequency regulation, and oscillatory membrane properties in lamprey spinal cord neurons. J Neurophysiol 61: 759-768.

Watson FL, Heerssen HM, Moheban DB, Lin MZ, Sauvageot CM, Bhattacharyya A et al (1999). Rapid nuclear responses to target - derived neurotrophins require retrograde transport of ligand - receptor complex. J Neurosci 19: 7889-7900. 
Weissman M, Bland RC, Canino GJ, Faravelli C, Greenwald S, Hwu $\mathrm{H}-\mathrm{G}$ et al (1996). Cross-national epidemiology of major depression and bipolar disorder. $J$ Am Med Assoc 276: 293-299.

Wilens TE, Cohen L, Biederman J, Abrams A, Neft D, Faird N et al (2002). Fluoxetine pharmacokinetics in pediatric patients. J Clin Psychopharmacol 22: 568-575.

Wong EH, Sonders MS, Amara SG, Tinholt PM, Piercey MF, Hoffmann WP (2000). Reboxetine: a pharmacologically potent, selective and specific norepinephrine reuptake inhibitor. Biol Psychiatry 47: 818-829.

Wyneken U, Marengo JJ, Villanueva S, Soto D, Sandoval R, Gundelfinger ED et al (2003). Epilepsy-induced changes in signaling systems of human and rat postsynaptic densities. Epilepsia 44: 243-246.

Wyneken U, Smalla K-H, Marengo JJ, Soto D, De la Cerda A, Tischmeyer W et al (2001). Kainate-induced seizures alter protein composition and $N$-methyl-D-aspartate receptor function of rat forebrain postsynaptic densities. Neuroscience 102: 65-74. York RD, Molliver DC, Grewal SS, Stenberg PE, McCleskey EW, Stork PJS (2000). Role of phosphoinositide 3-kinase and endocytosis in nerve growth factor-induced extracellular signal-regulated kinase activation via Ras and Rap1. Mol Cell Biol 20: 8069-8083.

Zarate Jr CA, Du J, Quiroz J, Gray NA, Denicoff KD, Singh J et al (2003). Regulation of cellular plasticity cascades in the pathophysiology and treatment of mood disorders: role of the glutamatergic system. Ann NY Acad Sci 1003: 273-291.

Zetterstrom TS, Pei Q, Grahame-Smith DG (1998). Repeated electroconvulsive shock extends the duration of enhanced gene expression for BDNF in rat brain compared with a single administration. Brain Res Mol Brain Res 57: 106-110.

Ziff EB (1997). Enlightening the postsynaptic density. Neuron 19: 1163-1174. 